\title{
Irish Water and Scottish Water: A Comparison
}

\author{
Rodney McDermott1 ${ }^{*}$, Brian Solan'1, Sarah McCord1', Kim Littlewood² \\ ${ }^{1}$ Belfast School of Architecture and the Built Environment, Ulster University, Belfast, UK \\ ${ }^{2}$ Open University, Milton Keynes, UK \\ Email: ^r.mcdermott@ulster.ac.uk
}

How to cite this paper: McDermott, R., Solan, B., McCord, S. and Littlewood, K. (2019) Irish Water and Scottish Water: A Comparison. Journal of Water Resource and Protection, 11, 1064-1089.

https://doi.org/10.4236/jwarp.2019.118063

Received: June 29, 2019

Accepted: August 27, 2019

Published: August 30, 2019

Copyright $\odot 2019$ by author(s) and Scientific Research Publishing Inc. This work is licensed under the Creative Commons Attribution International License (CC BY 4.0).

http://creativecommons.org/licenses/by/4.0/

\begin{abstract}
Rising costs of production and the need for capital investment in the public water supply network in Ireland, has placed a strong emphasis on the need for water conservation and tackling the current high levels of leakage (Department of the Environment, Community and Local Government, 2015) [1]. Consequently, Irish Water which is Ireland's national water utility has had to consider various business models and supply frameworks to demonstrate value for money. This has included those successfully implemented by Scottish Water. Therefore, the aim of this study was to compare both national utility providers in terms of structure and financial performance. The results of this study showed that both utility providers differed significantly. The Utility has, indeed, tried to achieve "too much too soon" (O'Leary, 2018 [2]; Donegal Now, 2016) [3]. Therefore, the initial results of this study suggest that, continuing to consider Scottish Water as the benchmark may generate unrealistic targets and expectations which in all probability may not be achieved.
\end{abstract}

\section{Keywords}

Irish Water, Scottish Water, Water Charges, Water Leakage, Water Utility

\section{Introduction}

The Scottish Water Corporation exemplar is playing a pivotal role in the development, design and implementation of a Water Industry Operating Framework in Ireland (Scottish Government, 2018) [4]. In this way, Irish Water has adopted the Scottish Water business model as a comparative benchmark to demonstrate value for money. This being the case, surely both utilities must have relatively similar financial models and priorities for asset improvement to ensure a fair unbiased comparison? If so, why has the financial model been a success in Scotland and not in Ireland? The Scottish Water utility model was one of the main 
exemplars used during the formation of the Irish Water utility (Scottish Water, 2015) [5] and continues to provide major input towards the design of the Water Industry Operating Framework (WIOF) in Ireland (Scottish Government, 2018) [4]. In their report, Price Waterhouse Cooper (PWC) (2011) [6] also highlighted Scottish Water as a particularly useful model to consider alongside the Irish Water utility, due to its experience in amalgamation of Local Authority Water Services. As a well-established utility and one of the most efficient in the UK, the Scottish Water model was deemed as providing a good architype of water service provider success (NIA, 2014) [7]. Meetings were held between the two bodies during which Irish Water sought the advice and perspectives of top Scottish Water management (Irish Water, 2014) [8] regarding best practice and strategies for the management of the project. However, in recent years, Irish Water has undergone detailed scrutiny, much of which has been negative, whilst Scottish Water has been praised regularly for the efficient service it provides. Given this paradox between seemingly similar organisations, it is interesting to note that little or no formal research has been completed directly comparing the two companies. It is this gap in the published literature that the current authors aimed to address.

\section{Review of Existing Literature}

The existing literature was reviewed in relation to revenue, operational expenditure $(\mathrm{OpEx})$ and capital expenditure (CapEx).

\subsection{Revenue}

Both Irish Water and Scottish Water are currently using very different methods to generate their finance. Following years of political debate and public outrage, Irish Water decided to abandon and refund volumetric domestic charges and is currently funded through general taxation (O'Regan, 2016 [9]; CRU, 2019) [10]. Plans are in place to reintroduce domestic charging in the form of an excess use charge, aided by the meters which were installed during a nationwide domestic metering programme (Citizens Information, 2018 [11]; Finn, 2016) [12]. In contrast, Scottish Water has never rolled out nationwide domestic metering. Instead, they charge customers based on their council tax bands (Scottish Water, 2019) [13]. Scottish Water has also recently introduced competition to their non-domestic market. The utility wholesales to licenced providers that retail their services to the non-domestic market (Utility Week, 2018) [14]. The usage of competition should ensure a fair and equitable service that provides value for money to end users, with quality being directly assured to the customers (WICS, 2010) [15]. Conversely, in Ireland, there is no competition in the non-domestic market because Irish Water charges its non-domestic consumers directly based on their volumetric usage (RPS and Veolia, 2010) [16]. Finally, Irish Water appears to have a high dependence on the Irish Government as a source of finance. This form of support is acceptable in time of economic growth and develop- 
ment; however, the financial crisis in recent decades means this source of revenue has been constrained. External financing is available in the form of grants, borrowing and shareholder capital (Blacklocke et al, 2014 [17]; Fitzgerald, 2018 [18]). However, Scottish Water has no access to share capital and is less than 10\% funded by the Scottish Government. During the 2015-2016 and 2016-2017 periods, Scottish Water received no additional government loans (Scottish Water, 2017 [19], Cuthbert 2018 [20]).

\subsection{Operational Expenditure}

Differences exist between Irish Water and Scottish Water in terms of activities related to operational expenditure. Whilst Irish Water is responsible for the provision of water in Ireland, these services are also provided by local authorities under a series of Service Level Agreements (SLAs) (Kennelly, 2018 [21]; Irish Water, 2013 [22]). Many believe that this has left the Irish water industry fragmented, expensive and has served as a barrier to efficient communication (Brennan, 2016 [23]; NERA, 2016 [24]). Experience has shown that adding layers of bureaucracy creates inefficiencies which ultimately impacts the quality of the service provided. Consequently, Irish Water continues to be criticised in the national press and has been scrutinised for many reasons including consultancy charges, bonus payments and staff salaries (O’Regan, 2016 [9]; Finn, 2017 [25]; Duffy, 2014 [26]). Similarly, Scottish Water has also been at the centre of similar controversies (Hutcheon, 2019) [27].

Irish Water has faced leakage levels of almost 50\% (equating to approximately $833 \mathrm{Mil}$. L/day in 2014) and, in 2017, introduced a nationwide leakage reduction programme to reduce wastage (CER, 2017 [28]; Irish Water, 2015 [29]). Leakage in Scotland has been reduced to $492 \mathrm{Mil} \mathrm{L/day} \mathrm{and} \mathrm{has} \mathrm{achieved} \mathrm{its} \mathrm{calculated}$ economic level of leakage (ELL) (Scottish Government, 2018a [30]). Pressure on the current water supply infrastructure is ever-increasing. According to Blacklocke et al (2014) [17], the water supply in the Greater Dublin Area (GDA) has little or no spare capacity. Despite having a comparatively high rainfall throughout the year, water shortages are not uncommon in the GDA in summer, particularly following any lower than average winter rainfall. The current population of Dublin alone stands at 1.3 million and requires in the region of 550 million litres of water every day Blacklocke et al. (2014) [17]. Dublin City Council (2010a) [31] estimates the Water Supply Area (WSA) will see the population increase to 2.2 million people by 2031, utilising around 800 million litres per day. During the census of 2016, the population of Dublin was reported to be $1,173,179$, a 5.6\% increase from the 2011 census Central Statistics Office (2018) [32]. The total population of Ireland in 2018 was calculated to be $4,857,000$, an $8.29 \%$ increase on the 2008 population $(4,485,100)$. These changing demographics means Irish Water needs to upgrade and modernise the water supply in the GDA which will require significant capital expenditure. However, changes in populations and demand are unlikely to be a problem Scottish Water will face due to the 
abundance and evenly distributed rainfall across Scotland and the quality of their supply network.

Another barrier, to the efficient operation and management of Irish Water, is the lack of available knowledge surrounding the current asset inventory (Irish Water, 2015) [29]. A similar problem was faced by Scottish Water in its formative years, when significant time and effort was directed towards formalising asset inventory (Audit Scotland, 2005) [33]. Irish Water has more than double the operating costs of the UK benchmark and was set a target reduction of $20 \%$ from 2015 to 2018 (Irish Water, 2015 [29]; CER, 2016 [34]). However, real operating costs are expected to rise $13 \%$ by 2021 as a result of growth and expansion (Irish Water, 2015 [29]; CER, 2016 [34]). By contrast, Scottish Water has made continuous and ongoing efforts to increase their efficiency including research into new technology that reduces the likelihood of pipe bursts and by increasing its capacity for renewable energy (Utility Week, 2017a [35]; W\&WT, 2019 [36]).

\subsection{Capital Expenditure}

A major problem identified with Irish Water's capital is its dependence on a Victorian-built infrastructure (Blacklocke, et al. 2014) [17]. It has been reported that Irish Water will spend approximately $€ 370$ million over a 10 -year period on the replacement of lead pipes (O’Brien, 2016) [37]. In addition to the high number of ongoing boil water notices (BWNs) in Ireland, there is also a significant number of waste water treatment plants in Ireland that are discharging raw sewage or have discharges that are non-compliant with European standards. Consequently, Irish Water was before the European Court of Justice for its failure to comply with both the Drinking Water Directive (DWD) (EC, 1998) [38] and the Urban Waste Water Treatment Directive (UWWTD) (EC, 1991) [39]. Therefore, significant capital expenditure will be required over the upcoming years to bring Ireland's water infrastructure up to the necessary standards (EPA, 2018 [40]; EPA, 2018a [41]). Furthermore, huge levels of capital investment will be required just to maintain the current service conditions which means a continuation of the failure to meet current European standards and associated fines (Brady \& Gray, 2018) [42]. This type of public censure from the European Commission (EC) may further erode public confidence in a utility that has significant ongoing PR problems.

It is important to note that whilst Scottish Water has proven itself in recent years by successfully achieving European standards and meeting targets set by the Water Industry Commission for Scotland (WICS), this was not always the case. In its early years, Scottish Water faced many of the same problems that Irish Water is currently facing. Scottish Water struggled with the quantity and quality of assets available with much time and effort directed towards the formalising available data (Audit Scotland, 2005) [33]. Many years of under-investment had left Scottish Water's assets in poor condition. Over a 15-year period, $£ 5$ billion was spent to ensure compliance with European Union (EU) 
directives (Dickie and Sawkins, 2001) [43]. Byatt (2012) [44] reflected on a "clumsy assessment" of environmental and water obligations which would have led to a hugely expensive capital investment programme and subsequently an $88 \%$ rise in prices. The WICS proposed a much lower capital investment which was accepted by Scottish Water. It is worth noting that on occasions, Scottish Water has also struggled to complete its capital programmes within the required periods (Hendry, 2016) [45].

Capital expenditure currently accounts for approximately 50\% of Scottish Water's total expenditure (Hendry, 2016) [45]. In the regulatory period from 2015-2021, Scottish Water will spend $£ 3.9$ billion ensuring its infrastructure is "fit for purpose" now and in the years to come (Scottish Government, 2018) [4]. Scottish Water has committed to investing $£ 3.9$ billion between 2015-2021 with the aim of providing a water infrastructure for Scotland that will not only serve its current communities but also for decades to come (Scottish Government, 2018 [4]; KPMG, 2018 [46]). Thus, Scottish Water is adding resilience to its asset base by future proofing its infrastructure base.

\subsection{Summary}

In terms of capital investment and operational practices, Scottish Water may have faced similar problems to Irish Water in its formative years; however, there are now major operational and income generation differences between Scottish Water and Irish Water. Therefore, with Scottish Water International Limited (which is a subsidiary of Scottish Water) currently working as a subcontractor to Ernst \& Young on the development, design and implementation of the Water Industry Operating Framework in Ireland (Scottish Government, 2018) [4], it is vitally important to consider if Scottish Water should continue to be used as the comparative benchmark for transforming the future of Ireland's water industry.

\section{Method}

This study focused on three financial areas. Initially, revenue was studied, encompassing each utility provider's level of government borrowings and the associated charges to their respective consumer bases. Operational expenditure was then studied, not only as an indicator of the efficiency but also to provide a context of spending behaviours. However, this analysis concentrated on the capital expenditure profile, with a special focus on the percentage allocated towards the maintenance and upgrading of the current asset base. This gave insight into the main objectives and priorities of the organisations in terms of repairing or replacing defective assets. The conditions of some assets were considered to give an indication of the general state of the water industries within the two countries. This body of research involved a study of the financial accounts, Exchequer statements and relevant Commissioner publications over relevant operational years. Following the review of existing literature surrounding the two utilities, it 
was evident that further research was necessary. Table 1 shows the data sources used for the analysis. Table 2 shows the units used for the analysis of data.

Currency exchange rates tend to fluctuate as a result of the changing market within the respective countries. There are many factors affecting the market including inflation rates, government debt and political stability. However, perhaps the most influential factor on the value of the Great Britain Pounds (GBPE) over recent years has been Brexit. The Brexit vote took place on 23rd June 2016 and, since this date, mounting uncertainty has caused the value of the GBP£ to vary greatly over the past three years. For this reason, it has been decided that an average exchange rate was taken over the 2014-2018 period. For the conversion of Sterling $(\mathfrak{E})$ to Euro $(€)$, a standard conversion factor of 1.221 was adopted. This was calculated from an average figure using the daily rate over the past 5 years (OFX, 2019) [47].

The financial year runs from 1st April to 31st March in the UK whereas, in Ireland, the financial year runs from 1st January to 31st December. Due to differences in the financial years, the accounts were analysed by the year in which they end. This is summarised in Table 3.

Table 1. Data sources used for analysis.

\begin{tabular}{cc}
\hline Scottish Water Data Sources & Irish Water Data Sources \\
\hline Scottish Water & Irish Water \\
$\begin{array}{c}\text { Scottish Environment Protection } \\
\text { Agency-SEPA }\end{array}$ & Environmental Protection Agency-EPA \\
Water Industry Commission for \\
Scotland-WICS \\
$\begin{array}{c}\text { Drinking Water Quality } \\
\text { Regulator-DWQR }\end{array}$ \\
MarketLine \\
known as Commission for Energy Regulation-CER \\
KPMG \\
Office of the Comptroller and Auditor General \\
ERVIA \\
Department of Housing Planning and Local \\
Government-DHPLG \\
CH2M Hill
\end{tabular}

Table 2. Chosen units for analysis of data.

\begin{tabular}{cc}
\hline Measurement & Units \\
\hline Costs & Euro $(€)$ \\
Distances & Kilometres $(\mathrm{km})$ \\
Area & Sq. Kilometres $\left(\mathrm{km}^{2}\right)$ \\
\hline
\end{tabular}

Table 3. Explanation for comparison of accounts.

\begin{tabular}{ccccccccc}
\hline Year end & 2014 & 2015 & 2016 & 2017 & 2018 & 2019 & 2020 & 2021 \\
\hline Irish Water Accounts & 2014 & 2015 & 2016 & 2017 & 2018 & 2019 & 2020 & 2021 \\
Scottish Water Accounts & $2013-14$ & $2014-15$ & $2015-16$ & $2016-17$ & $2017-18$ & $2018-19$ & $2019-20$ & $2020-21$ \\
\hline
\end{tabular}


Due to time constraints of this study, the most recently published accounts available were for the 2017-2018 financial year as follows:

- Irish Water-2017 Financial Year [48].

- Scottish Water-2017-2018 Financial Year [49].

Any figures quoted beyond the extent of these accounts are forecast figures only. The adoption of International Financial Reporting Standards (IFRS Foundation, 2017) [50] has simplified accounting procedures and eased the auditing and analysis of accounts. As both Ireland and Scotland have signed up to these standards, comparisons could be achieved for the purpose of this study.

The comparison of both companies was normalised relative to the population that each company serves, with presenting monetary information per head of population. All values quoted in the text being actual monetary values unless otherwise stated. This ensures a rational and equitable basis of comparison. To provide a greater representation of the costs, they were divided by the population of their respective countries and, therefore, this cost or revenue was per population head.

- Most recent estimate of the Scottish population is 5,424,800 (National Records of Scotland, 2019) [51].

- Current population of Ireland is estimated to be 4,831,243 (Worldometers, 2019) [52].

\section{Results}

Results showed variations in assets, revenue, operational expenditure and capital expenditure between the two utility providers.

\subsection{Assets}

\subsubsection{Asset Quantity}

Irish Water produces approximately 0.32 billion litres more clean water and treats 271 million litres more wastewater than Scottish Water despite having almost $11 \%$ less population (Figure 1 and Figure 2 detail the asset inventory). Therefore, Irish Water is treating considerably more water and wastewater even when allowing for the age and condition of the existing asset stock (Blacklocke et al., 2014) [17]. There are three possible reasons for Irish Water treating this level of clean water including a higher level of water consumption in Ireland or water lost through leakage or poor operational practice. Ireland is deemed to be 62.95\% urbanisation, whereas Scotland's urbanisation is 72\% (Statista, 2017 [53]; National Statistics, 2011 [54]). Given the higher level of urbanisation in Scotland, it would be expected that there should be more properties feeding directly into the wastewater network and, therefore, necessitating a greater volume of wastewater treatment. However, this is not the case.

The smaller number of wastewater treatment plants in Ireland may be related to a lower level of urbanisation, compared to Scotland. The greater the percentage of the population living within or near a town or city, the more homes and 
businesses are connected directly to the wastewater network. In Ireland, which is less densely populated, it may be the case that a lot more homes have septic tank arrangements and, therefore, are not directly connected to a wastewater network.

Ireland has a total of 924 Water Treatment Plants (WTPs), in contrast to Scottish Water's 242 WTPs. Of the 924 WTPs in Ireland, approximately 235 are treating a volume greater than 1 million litres per day (Irish Water, 2015b) [29]. From this, there are approximately 700 WTPs in Ireland producing relatively small volumes of drinking water. All these WTPs, regardless of their size or output, require operational staff and maintenance, electricity supply and regular servicing and inspections. Thus, the legacy of assets within Irish Water has created a sequence of plants that serve as a significant financial drain on Irish Water. The continued operation of such a vast number of small plants is questionable; however, local service demands, geographic distances and available financial resources mean that this situation cannot be remedied quickly. This is reflective of the fragmented nature of the utility in its formative years and it is likely to change as the utility develops from its historic local authority-based strategy to a nationwide utility.

The greater the number of assets, the greater the expenditure involved. This expenditure includes the capital expenses required to build and maintain, daily operating expenses due to power usage, treatment processes and trained operating staff requirements. Is there room to eliminate some of the smaller plants and/or reservoirs and create a more streamlined utility? This is a question that Irish Water needs to address to ensure the future of the organisation.

\subsubsection{Assets}

The main assets and outputs of Scottish Water and Irish Water utilities are illustrated in Figure 1 and Figure 2. Scottish Water serves an area of 80,239 square $\mathrm{km}$ whilst Irish Water serves an area of 69,825 square $\mathrm{km}$.

\subsubsection{Asset Quality}

Figure 3 illustrates that Irish Water still has a relatively high level of leakage. Current estimates suggest a rate of $44 \%$ despite ongoing efforts, such as the 2017 National Leakage Reduction Programme. Metering may have aided in lessening the asset information deficit; however, further improvement work is still required in this area. Scottish Water has achieved its economic level of leakage yet is still losing approximately $482 \mathrm{ML} /$ day, approximately 35\%. However, Article 9 of the Water Framework Directive (WFD) (EC, 2000) [59] encourages water conservation, aiming for minimal wastage. Therefore, there is room for improvement, in terms of leakage, for both utility providers. It is interesting to note that both organisations have similar rates of improvement in terms of addressing water leakage; however, despite this, it is likely that both companies will continue to have legacy issues with the ageing pipe network they inherited. Although compliance with the Drinking Water Directive (DWD) (EC, 1998) [38] 
and the Urban Wastewater Treatment Directive were also assessed (UWWTD) (EC, 1991) [39], no suitable diagram could be drawn due to the variability between the two utilities.

Ireland has made substantial strides in terms of its compliance with the DWD (EC, 1998) [38] but there is still a large proportion of remediation/upgrade schemes remaining on the Environmental Protection Agency's (EPA) remedial action list (EPA, 2019) [60]. There are also many wastewater treatment plants in Ireland that are not fully compliant with the UWWTD (EC, 1991) [39]. Irish

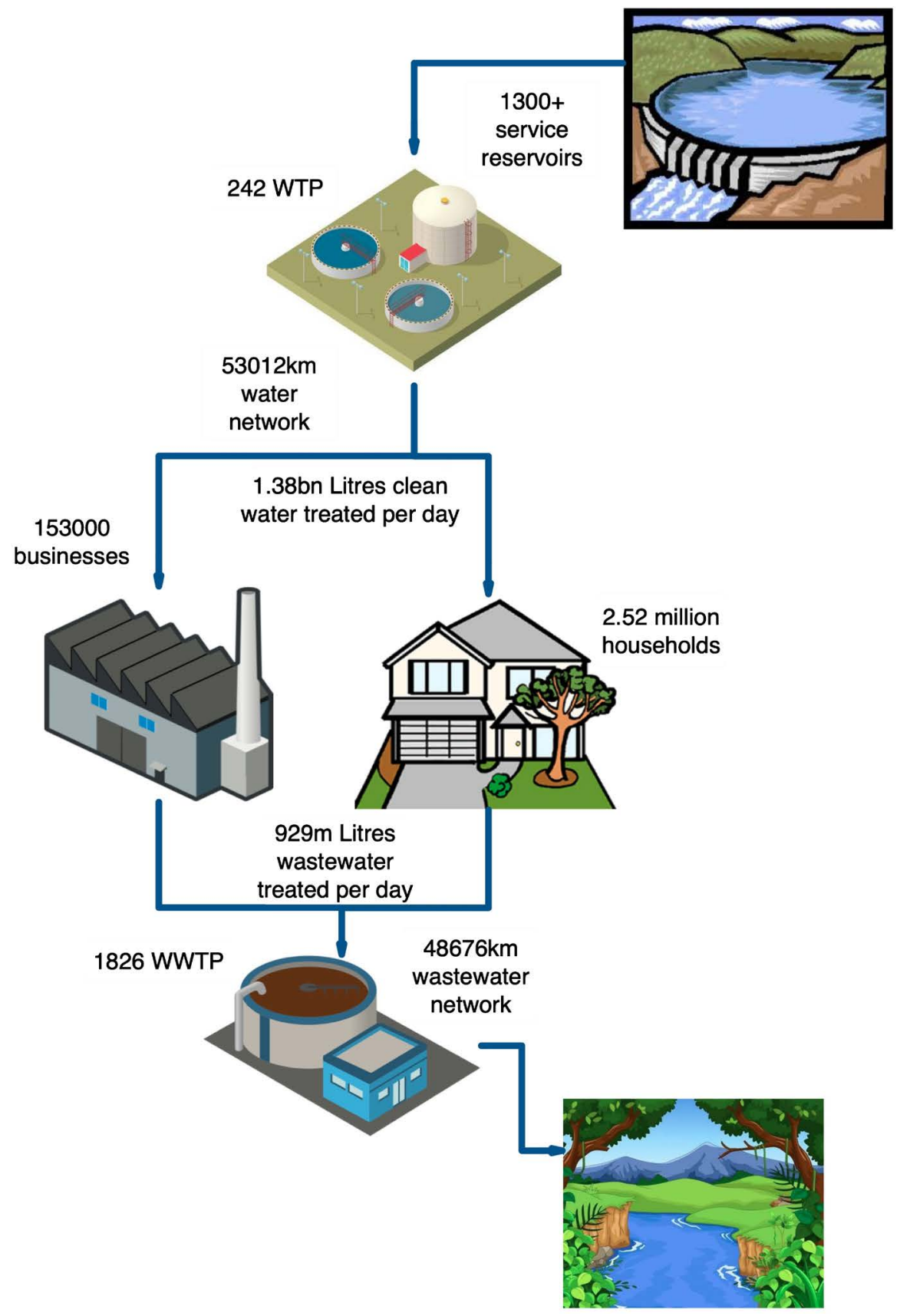

Sources: Scottish Water, 2018 [49]; Scottish Water, 2018a [55]; MarketLine, 2018 [56].

Figure 1. Overview of Scottish Water asset base. 


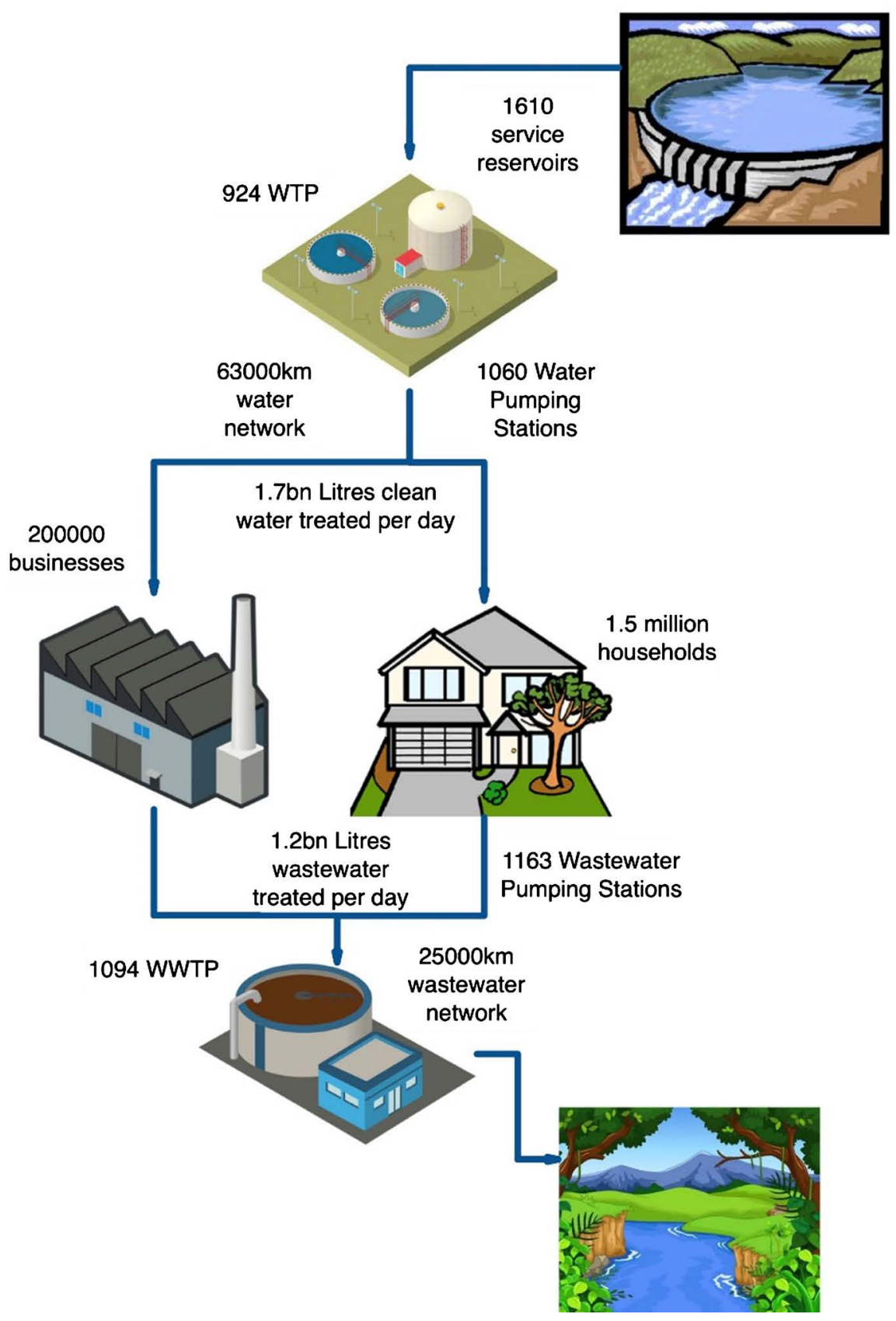

Sources: Irish Water, 2015 [29]; Irish Water, 2016a [57]; Irish Water, 2018 [58].

Figure 2. Overview of Irish Water assetbase.

Water has aimed for full compliance by $2023-18$ years after the deadline set by the EC. However, most wastewater treatment plants in Scotland are now fully compliant with the UWWTD (EC, 1991) [39] and, in most cases, water quality is at a very high level (Scottish Water, 2018) [49].

\subsection{Revenue}

Figure 4 shows that Scottish Water's revenue per head of population is rising steadily but at a lower rate of increase when compared with Irish Water. The 


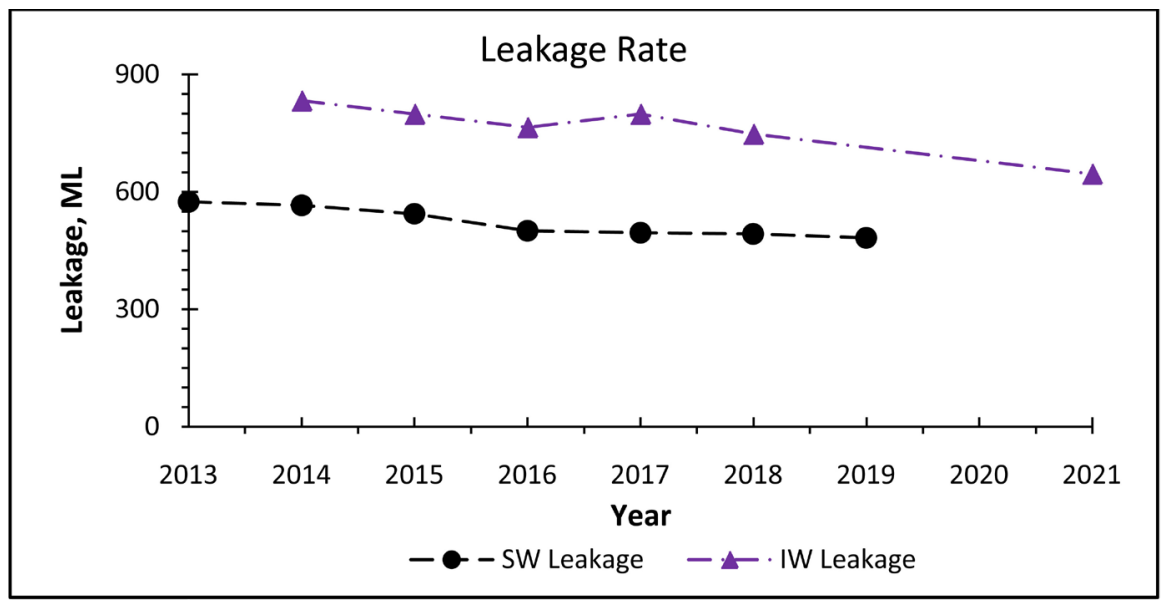

Sources: CER, 2017 [28]; Irish Water, 2015 [29]; CER, 2016 [34]; Irish Water, 2017 [48]; Irish Water, 2018b [61]; WICS, 2013 [62]; WICS, 2014 [63]; WICS, 2015 [64]; WICS, 2016 [65]; WICS, 2017 [66]; WICS, 2018 [67]; Scottish Water, 2019a [68].

Figure 3. Chart showing leakage rate for both utilities.

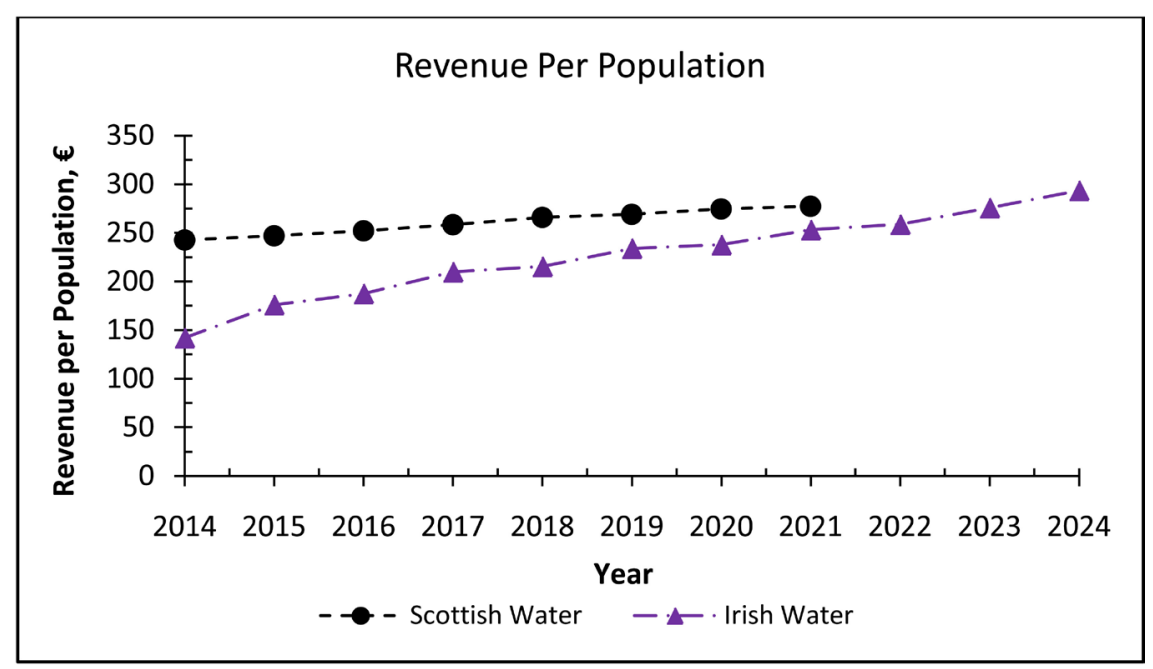

Sources: Scottish Water, 2015 [5]; Scottish Water, 2017 [19]; Irish Water, 2015 [29]; Irish Water, 2017 [48]; Scottish Water, 2018 [49]; Scottish Water, 2018a [55]; Irish Water, 2018 [58]; Irish Water, 2016 [69]; Irish Water, 2018a [70]; Scottish Water, 2016 [71].

Figure 4. Chart showing historic and projected revenues for both utilities divided by their estimated populations taking into consideration the Irish Water domestic charges refund.

actual results are rising from $£ 1078.2$ million ( $€ 1316.5$ million) in 2014 to an anticipated $£ 1233$ million (€1505.5 million) in 2021 (Scottish Water, 2015 [45]; Scottish Water, 2018a [55]). Irish Water's revenue per head of population is rising at a greater rate from $€ 687$ in 2014 to an anticipated $€ 1223$ by 2021 (Irish Water, 2016 [69]; Irish Water, 2018a [70]).

Irish Water's borrowing levels are significantly higher than that of Scottish Water. However, when considering total borrowing levels, Irish Water's borrowing per head of population reduced significantly in 2015 (Figure 5). This may have been due to the expected income from domestic charging. Even at this lowest level in 2015, Irish Water's borrowing is still greater than that of Scottish 
Water. Total borrowing for Irish Water is expected to grow at a steady rate from 2015 to 2020, falling to $€ 465$ million in 2021 then rising again to $€ 803$ million in 2024 (Irish Water, 2018a [70]; Office of the Comptroller and Auditor General, 2017 [72]; Office of the Comptroller and Auditor General, 2018 [73]). There is no clear reason for this sharp decline in borrowing in 2021 and, on examination of Figure 4, there has been no corresponding increase in revenue to counteract this loss in income. Irish Water's anticipated shareholder capital contributions and government loans were not available for 2018 and, therefore, it is thought that these figures will be in line with the historic and projected borrowings.

Both Irish Water and Scottish Water have not relied solely on their revenue to fund capital programmes or operations but have also required additional funding in the form of borrowing (Figure 5). It is important to note that Scottish Water can only access borrowings from the Scottish Government. In contrast, Irish Water can also borrow from banks or other financial institutions. For the purposes of this study, only government borrowing was considered as year-on-year bank loans were not demarcated clearly within the relevant financial statements.

Scottish Water had anticipated borrowing levels of $£ 120$ million in their 2015-2021 Business Plan (Scottish Water, 2014) [74]. However, their current annual financial reports have shown their borrowings to be significantly lower than expected. Government borrowing in 2015 was $£ 70$ million ( $€ 85.5$ million) and, during 2016 and 2017, there was no additional borrowing from government (Scottish Water, 2016 [71]; Scottish Water, 2017 [19]). As highlighted by Cuthbert (2018) [20], investment programmes over this 2-year period were funded without additional borrowing. Despite this, $£ 760$ million ( $€ 928$ million) of borrowing has been agreed over the period of 2018-2021 (Scottish Water, 2018a) [55]. This has

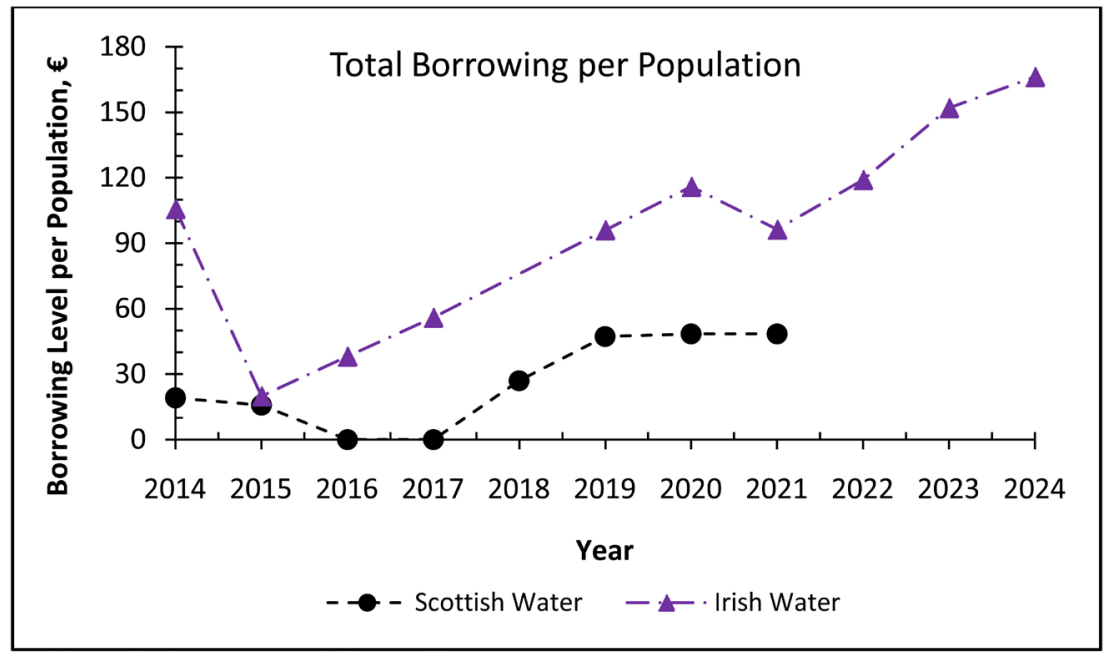

Sources: Scottish Water, 2015 [5]; Scottish Water, 2017 [19]; Irish Water, 2017 [48]; Scottish Water, 2018 [49]; Scottish Water, 2018a [55]; Irish Water, 2016 [69]; Scottish Water, 2016 [71]; Office of the Comptroller and Auditor General, 2017 [72]; Office of the Comptroller and Auditor General, 2018 [73].

Figure 5. Borrowing per head of population, including Irish Water's income from shareholder capital contributions. 
led to an anticipated increase in government borrowing to $£ 215$ million ( $€ 263$ million) in 2020 and 2021 (Scottish Water, 2018a) [55]. Scottish Water's ability to generate efficiency and, hence, outperform its anticipated operating costs allows it to build up cash balances. This then enables Scottish Government to defer its lending and benefits customers because interest on loans is reduced. Crucially, it also allows Scottish Government to divert spending to other essential services.

Figure 6 shows the total income for the two utilities, encompassing any revenue sources, loans and, for Irish Water only, shareholder capital contributions. The general trend shows a rise in income for both utilities. Irish Water's income shows a significant drop in 2015 which could perhaps be due to the lower net government loans in comparison to previous and preceding years. Net loans are likely to have been decreased in this year due to the anticipation of increased income from domestic charging (Irish Water, 2016 [69]; Irish Water, 2018a [70]; Office of the Comptroller and Auditor General, 2017 [72]; Office of the Comptroller and Auditor General, 2018 [73]). From 2015 onwards, total income increases for both utilities. By 2017, Irish Water's total income had exceeded that of Scottish Water. However, it is important to consider the exact source of its income.

A review of the published data confirms that Irish Water is highly dependent on the Irish Government to provide a secure source of income (Figure 7). Most of the income over the period 2014-2024 originated from a combination of shareholder capital contributions and government subvention with only $19.8 \%$ of income over the 10-year period coming from consumer charges. The lack of

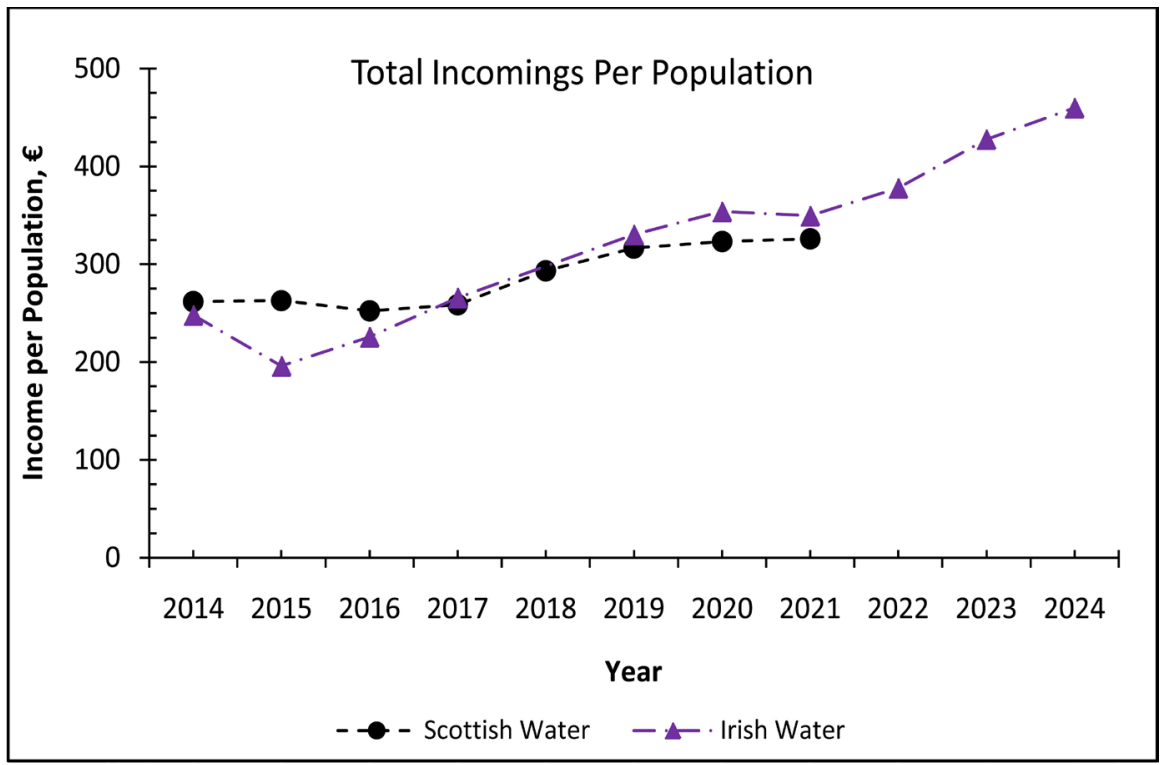

Sources: Scottish Water, 2015 [4]; Scottish Water, 2017 [19]; Irish Water, 2015 [29]; Irish Water, 2017 [48]; Scottish Water, 2018 [49]; Scottish Water, 2018a [55]; Irish Water, 2018 [58]; Irish Water, 2016 [70]; Irish Water, 2018a [71]; Scottish Water, 2016 [72]; Office of the Comptroller and Auditor General, 2017 [72]; Office of the Comptroller and Auditor General, 2018 [73].

Figure 6. Total income including revenue and borrowing per head of population. 


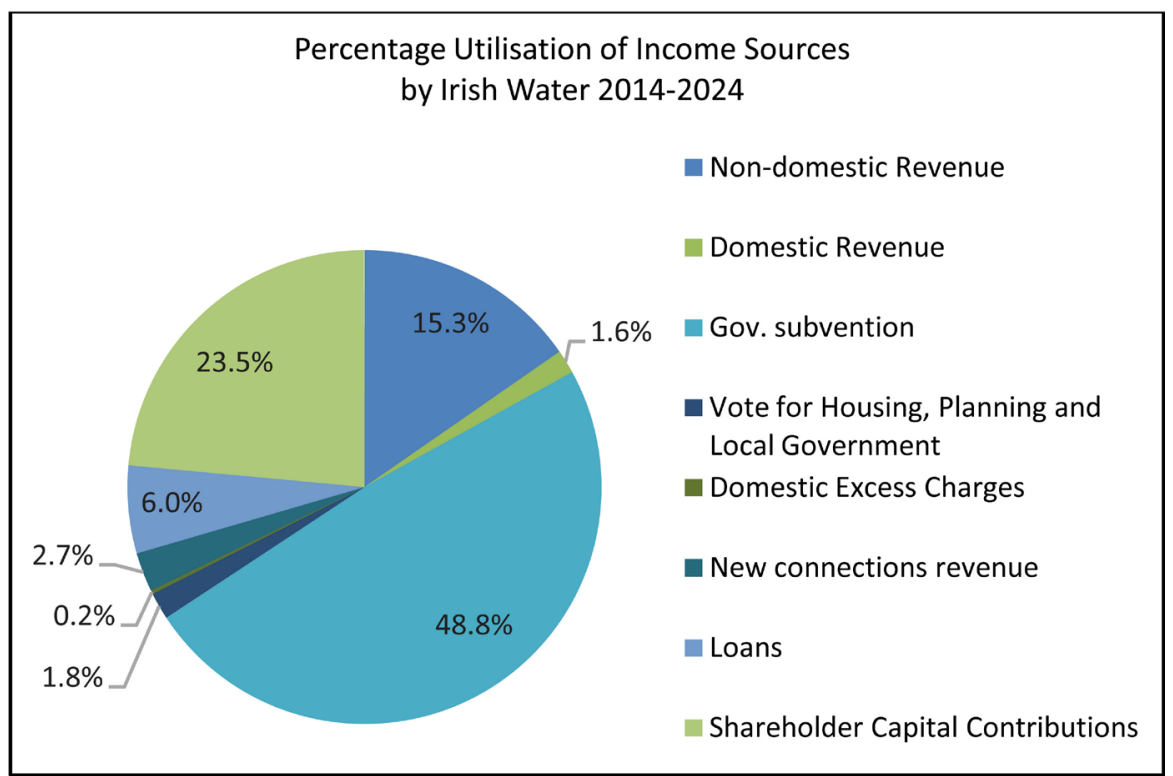

Sources: Irish Water, 2015b [29]; Irish Water, 2017 [48]; Irish Water, 2018 [58]; Irish Water, 2016 [69]; Irish Water, 2018a [70]; Office of the Comptroller and Auditor General, 2017 [72]; Office of the Comptroller and Auditor General, 2018 [73].

Figure 7. Utilisation of income sources by Irish Water 2014-2024.

domestic charging in Ireland is a direct violation of the Water Framework Directive's (EC, 2000) [59] requirement for "full cost recovery". The failure of domestic charging in Ireland has been twofold-the historic lack of transparency within the Irish Water industry and the use of charges as a political incentive (Rodriguez-Sanchez et al, 2018) [75]. In contrast, Scottish Water has achieved a level of trust with its consumers through the provision of a consistent level of excellent service and transparency in all its communications. This has helped facilitate it to collect approximately $90 \%$ of its income from consumers. The utility is less than $10 \%$ government-funded and external finance comes only in the form of loans as needed (Figure 8).

\subsection{Operational Expenditure (OpEx)}

The review of OpEx also returned insightful results. The operational expenditure of Irish Water is significantly higher than its benchmark model from Scottish Water (Figure 9). Irish Water's OpEx is anticipated to rise from $€ 794$ million in 2014 to $€ 848$ million by 2024 (Irish Water, 2016 [69]; Irish Water, 2018a [70]). This is likely caused, in part, by the scale of the asset base of Irish Water. Another contributing factor may be the SLAs (Irish Water, 2013) [22] currently in operation. These have left Irish Water restricted in its ability to make sufficient cuts and reduce its operational expenditure (Brennan, 2016 [23]; Irish Water, 2018 [57]). In contrast, Scottish Water's OpEx is expected to fall slightly from $€ 629$ million in 2014 to €614 million by 2021 (WICS, 2013a [76]; WICS, 2015 [64]). Scottish Water has actively reduced its operational expenditure through changes in its operational practices and alterations to its asset base. WICS plays 


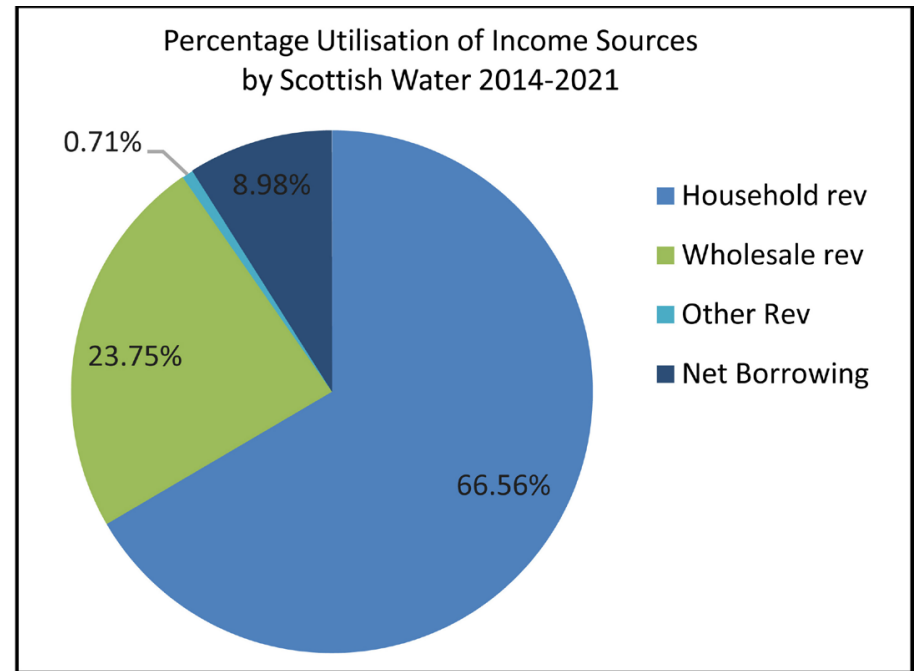

Sources: Scottish Water, 2015 [4]; Scottish Water, 2016 [66]; Scottish Water, 2017 [19]; Scottish Water, 2018a [53]; Scottish Water, 2018b [70].

Figure 8. Utilisation of income sources by Scottish Water 2014-2021.

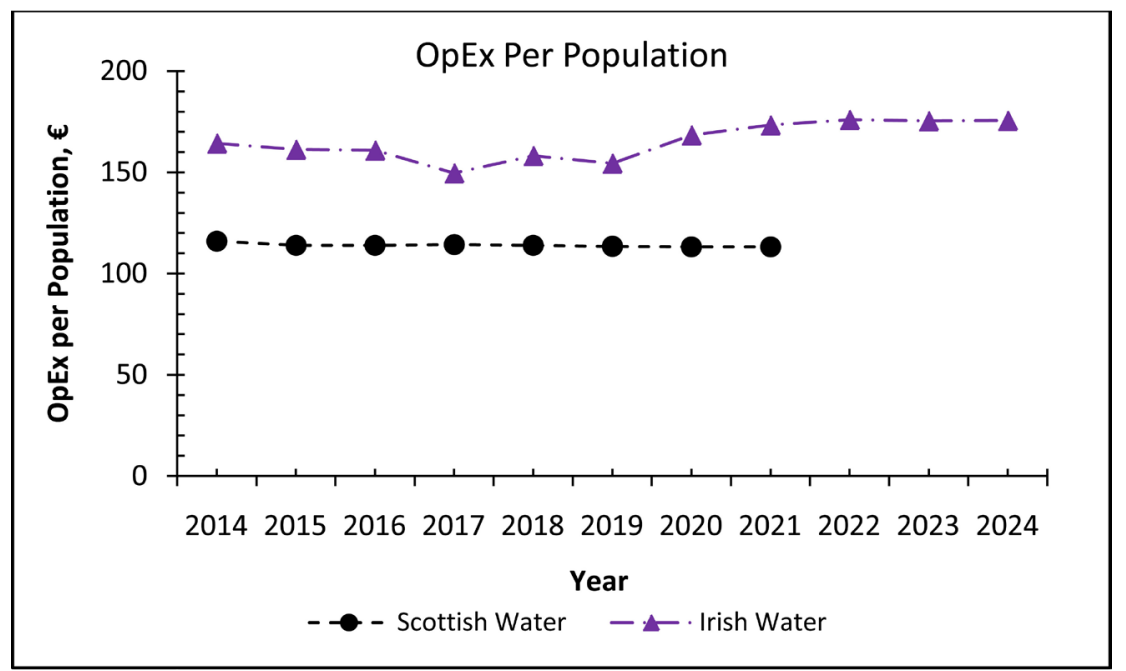

Sources: CER, 2016 [34]; Irish Water, 2017 [48]; Irish Water, 2018 [58]; WICS, 2013 [62]; WICS, 2014 [63]; WICS, 2015 [64]; WICS, 2016 [65]; Irish Water, 2018a [70]; WICS, 2013a [76]; WICS, 2017a [77]; WICS, 2018b [68].

Figure 9. Chart showing Operational expenditure per head of population.

an active role in driving operation efficiencies. This is evidenced in the consistent and sustainable rate at which the OpEx is decreasing year-on-year.

\subsection{Capital Expenditure (CapEx)}

Irish Water's CapEx in general is increasing but with little consistency (Figure 10). CapEx rose from €644 million in 2014 to $€ 831$ million in 2015 in terms of actual CapEx (Irish Water, 2015) [29]. Capital expenditure fell to €533 million in 2017, however, it is expected to rise to $€ 1360$ million by 2024 (Irish Water, 2018a) [70].

The inconsistent nature of Irish Water's capital spend is likely to be a result of the failure in adopting domestic charging and securing its own source of income. 
From a review of the breakdown of expenditure, it is clear that Irish Water's emphasis is on capital enhancement with a very small proportion being spent on capital maintenance (Figure 11). Irish Water's capital expenditure is projected to rise significantly over the period 2019-2024; however, achieving this level of expenditure is dependent upon the success of Irish Water in securing a viable income stream (Brady and Gray, 2017) [42].

Scottish Water's capital expenditure continues to rise annually in a consistent and sustainable manner (Figure 10) from $€ 580$ million in 2014 to a projected spend of $€ 957$ million in 2021. It has a balanced approach to its capital maintenance and capital enhancement, with roughly half of the budget being spent on each (Figure 11).

\subsection{Implications for Future Financing}

The populations of both Ireland and Scotland are projected to rise significantly over the coming years (Figure 12). By 2050, the population of Ireland is expected to grow beyond that of Scotland. At that stage, the population in Scotland is expected to be in the region of 5.77 million. For the same year, the population in Ireland is expected to be 5.79 million. This will have a substantial impact on water utilities and their ability to meet the needs of future generations. Weather patterns induced by climate change will also radically impact future water demands which both utilities need to build into their respective financial models.

In general, Scottish Water is meeting the needs of its consumers. WICS and Scottish Water are working together alongside the Scottish Government to ensure they plan now for the future of their water industry to avoid any shock increases in charges in the future. In contrast, Irish Water is struggling to meet the needs of its consumers. The suggested rate of growth for the population is likely to have significant impacts on water resources. Its ability to secure a viable source of finance will be fundamental to its ability to future proof the water provision in Ireland.

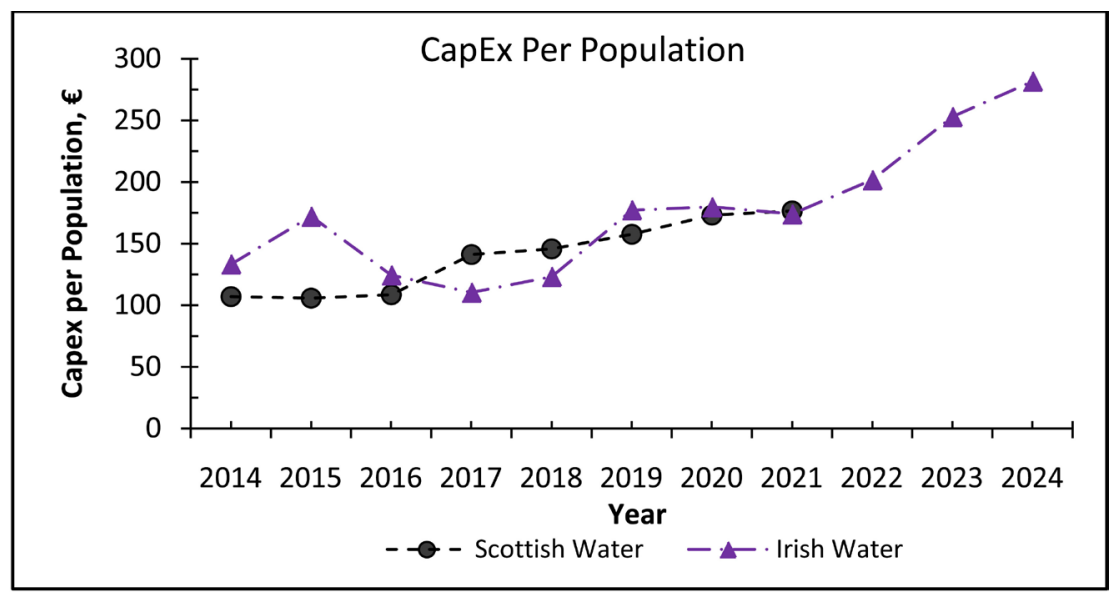

Sources: Scottish Water, 2015 [5]; Scottish Water, 2017 [19]; Irish Water, 2018a [55]; Irish Water, 2018a [70]; Scottish Water, 2016 [71].

Figure 10. Chart showing capital expenditure per head of population. 


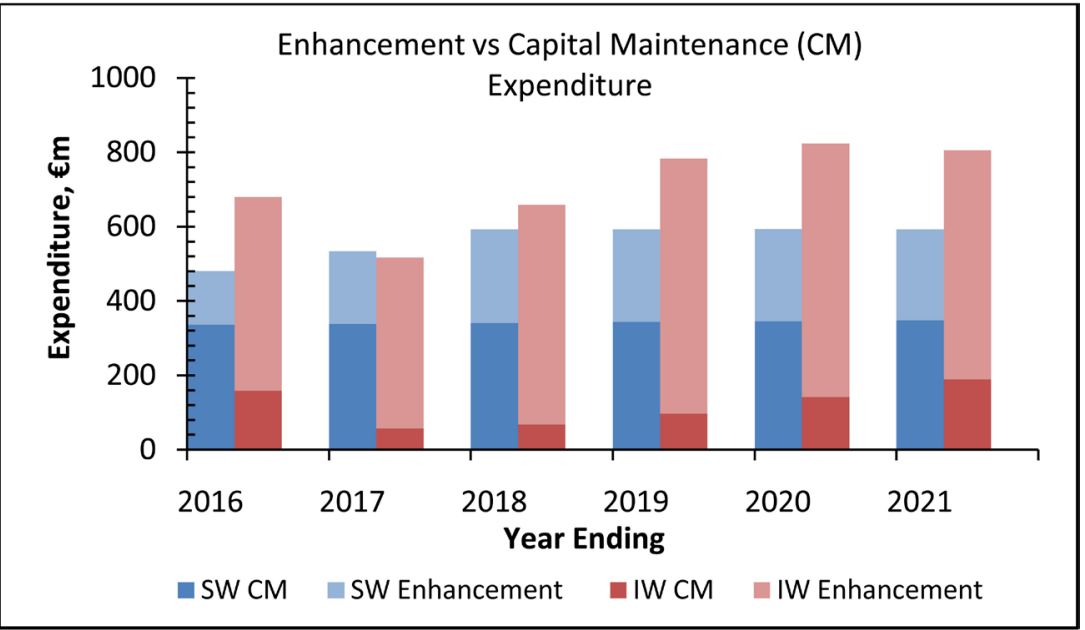

Sources: NERA, 2016 [24]; CER, 2016 [34]; CH2M Hill, 2014 [78]; CRU, 2018a [79]; Irish Water, 2016b [80]; Scottish Water, 2014a [81].

Figure 11. Chart showing capital expenditure in terms of maintenance and enhancement 2016-2021.

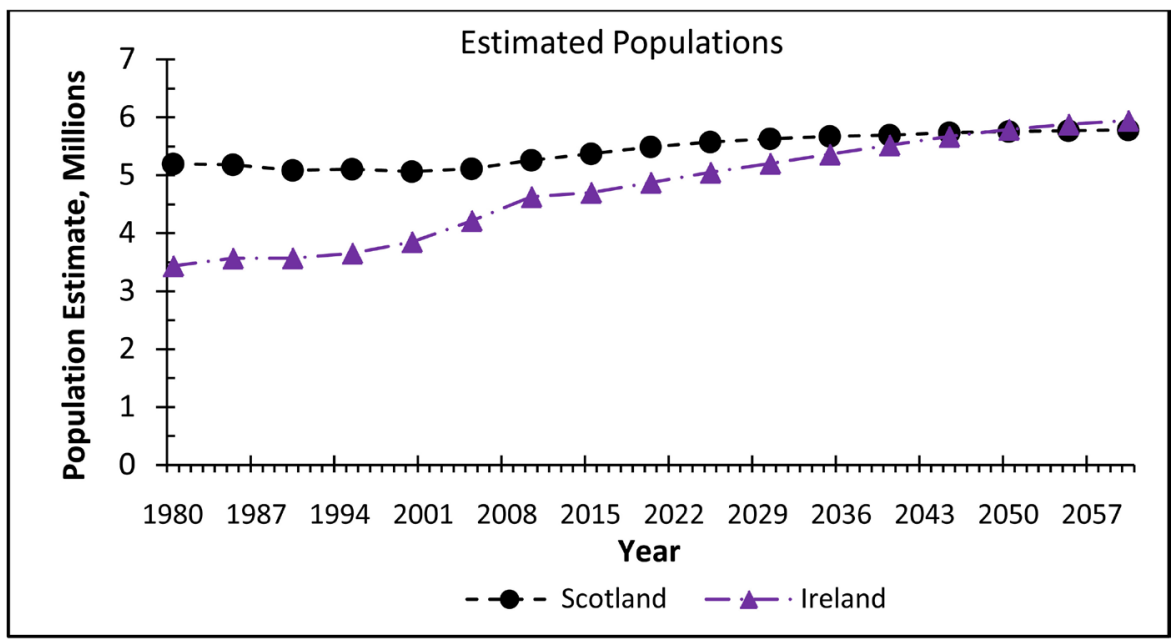

Sources: NRS, 2019 [51]; Population Pyramid, 2019 [82].

Figure 12. Historic and predicted population changes for Ireland and Scotland from 1980 to 2060 .

\section{Conclusions and Recommendations}

Based on the comparison of the two companies, the data suggests that neither of the two utilities is perfect. What is evident, throughout the study, is the success of the relationship between Scottish Water and its Regulator WICS. As stated by Byatt (2012) [44], the Regulator is only as successful as its relationship with the company. This is evidenced in the regularity of its incomes and expenses over the review period. One of the key lessons from the Scottish model was the company's success at bringing the general public with them on the journey. Scottish Water provides its customers with a quality service and charges for this essential commodity which is accepted by the general public. This is a lesson that has not 
been realised in Ireland and water charges remain a source of contention with the general public.

No direct parallels can be drawn between the finances of the two utilities. Irish Water is dependent on the Irish Government as its main source of income via a combination of grants, loans and shareholder capital contributions. This is a vulnerability for Irish Water which is dependent on a buoyant economy to ensure funding for the operation and upkeep on the existing asset stock. In terms of consumer charging, Irish Water has not yet established a successful source of income from direct consumer charges. Based on the reaction of the general public at the idea of charges and the unwillingness of politicians to champion the cause in times of financial hardship, it is highly unlikely that charges will be implemented anytime soon. Thus, Irish Water will need to explore alternative avenues of funding and, to achieve this, there needs to be a detailed review of the existing assets and proof of ownership for use as collateral against any future loans. There are anecdotal stories in circulation of WTPs on third party land which, if true, would render the assets value questionable as collateral. Expansion of the shareholder base is another possibility for Irish Water; however, the significant negative press, combined with failing to meet EC targets are issues that need to be addressed. Scottish Water has no access to shareholder capital contributions in the way that Irish Water has. Instead, Scottish Water collects over $90 \%$ of its income from consumer charges supplemented by Government borrowings only when necessary.

With respect to OpEx, Irish Water's spend is significantly higher than that of Scottish Water. This is likely to be a result of the scale of the Irish Water's asset base and increasing costs related to the SLAs (Irish Water, 2013) [22]. Scottish Water's ongoing efforts to reduce operational costs have been successful thus far and, in recent years, have outperformed targets, building up cash balances and deferring Government lending.

In terms of their capital expenditure, the two utilities have very different priorities. Scottish Water has a balanced approach to capital maintenance and enhancement, whereas Irish Water spends most of its CapEx on enhancement of its assets. Considering the ratio of assets between the two utilities, this is particularly interesting. Irish Water, which has for the most part more assets to maintain, is spending significantly less in this area. This approach may yield short term gains but may also result in problems in the future as the existing asset base comes to the end of its design life. Changing design standards and the need to manage the natural environment will also prove problematic in the future, for example, removal of antibiotics from wastewater discharges (Tretsiakova McNally et al., 2019) [83].

Even after almost 5 years in operation, very little is still known about the quantity and conditions of water and wastewater assets in Ireland. However, with approximately 63 WTPs and 24 wastewater agglomerations still not meeting the necessary European standards, what is certain is that much work will be 
required in Ireland over the coming years to ensure that the utility meets the necessary requirements of the EC and increased demand from projected rising population figures.

The problems faced by the two utilities in their establishment are undeniably similar and, from "a superficial glance", Scottish Water could provide a suitable example for Irish Water. Granted, Irish Water may indeed learn from the issues faced by Scottish Water in its founding years and how they dealt with them. Irish Water and Scottish Water are now at two completely different stages of maturity. From a review of the related literature, Irish Water has indeed tried to achieve "too much, too soon" as Deputy Gallagher and O'Leary have suggested (O’Leary, 2018 [2]; Donegal Now, 2016 [3]). This may be aggravated by its intention to model itself on a more mature utility provider and the starkly different income models that each company uses.

Based on the analysis conducted, both utilities differ significantly in terms of asset inventory legacy, conditions of operation and the cultural attitudes regarding water charges. Irish Water needs to have achievable targets that are fully risk assessed. For example, the campaign to reduce water usage is important as, in certain conditions, reduced water usage in dwellings can cause an increased number of sewer blockages which, therefore, can impact negatively on public health (McDermott et al., 2019) [84].

The Irish Government has not enacted legislation to rule out the possibility of the privatisation (or partial privatisation) of Irish Water. The bill tabled by Joan Collins TD in Dail Eireann proposed a referendum to amend Article 28 of the Constitution (Kelly, 2018) [85]. Whilst the bill has been passed, the constitutional changes called for by Deputy Collins have not been made.

The future sustainability and financial viability of Irish Water are threatened by funding sought by other vital public services including health, education and housing. With these competing services and factors such as the increasing and ageing population, one is compelled to ask how Irish Water can achieve efficiencies. There are several areas where further research is required-examples are as follows:

1) Unaccounted for Water (UFW): Irish Water must explore a reduction in UFW through specific engineering interventions such as mains rehabilitation/replacements, leakage reduction programme and behavioural change campaigns.

2) The use of Gravity in Design: Design making decisions should look for a gravity flow approach, where possible, to reduce or eliminate pumping costs for treatment and distribution of water intended for human consumption. The cost of pump provision, maintenance and replacement creates costs along with increasing the carbon footprint associated with the process. ATV advertisement by Irish Water (2019) [86] may result in some consumers having a better appreciation of water, highlighting that every drop of water supplied must be collected, treated and pumped through a vast network of pipes. However, the reference to 
the word "pumped" in the advert is not reflective on the overall network as there are numerous scenarios where water does not have to be pumped through the pipe delivery network. Nonetheless, smart designs are required to reduce pumping which can help reduce costs and carbon footprints.

3) Value Engineering: there is a wide variety of solutions available to deal with design briefs, for example, where the use of low-pressure sewer systems is being considered alternatives to "grinder pumping stations" should be considered through value engineering and whole-life costings.

4) Water Conservation: Sewer blockages are on the increase whilst water closet (WC) flush volumes are on the decrease (McDermott et al., 2019) [84]. Consequently, lower flush volumes reduce solids transfer in sewers. Therefore, sewer design standards need to be revised to keep up with water conservation.

5) Climate change: The storage and treatment of water will prove challenging to a utility which has an antiquated network, which in many locations is reaching the end of its useful design life. Studies could be undertaken to see how this critical factor will impact the spend and maintenance profile of the company.

6) Stress testing the revenue stream: The proposed financial models that underpin the current development plans should be tested for varying income scenarios including future financial recessions. As it stands, Irish Water has recently been ordered to cut costs by $€ 100$ million (Brennan, 2019) [87].

\section{Conflicts of Interest}

The authors declare no conflicts of interest regarding the publication of this paper.

\section{References}

[1] Department of the Environment, Community and Local Government (2015) Paper 1 -Overview of the Water Sector in Ireland.

https://www.cso.ie/en/media/csoie/newsevents/documents/irishwater/1overviewoft hewatersectoriireland.pdf

[2] O'Leary, J. (2018) How (Not) To Do Public Policy: Water Charges and Local Property Tax. Whitaker Institute. NUI Galway.

[3] Donegal Now (2016) Donegal TD Says Irish Water Is “a Failed Entity”. https://www.donegalnow.com/news/donegal-td-says-irish-water-is-a-failed-entity/8 $\underline{8716}$

[4] Scottish Government (2018) Scotland: The Hydro Nation Annual Report 2018. https://www.gov.scot/publications/scotland-hydro-nation-annual-report-2018/

[5] Scottish Water (2015) Annual Report and Accounts 2014/15. Scottish Water, Dunfermline, UK.

[6] Price Waterhouse Coopers (PWC) (2011) Irish Water: Phase 1 Report. https://www.housing.gov.ie/sites/default/files/migrated-files/en/Publications/Enviro nment/Water/FileDownLoad\%2C29193\%2Cen.pdf

[7] Northern Ireland Assembly (NIA) (2014) An Examination of Models within the Water and Sewerage Industry in the UK and Republic of Ireland. Northern Ireland Assembly. 
[8] Irish Water (2014) Scottish Water Executive \& Irish Water Management Team, Meeting Agenda.

https://www.whatdotheyknow.com/request/249964/response/623677/attach/html/4/ Untitled.pdf.html

[9] O’Regan, M. (2016) Irish Water Splashes $€ 5 \mathrm{~m}$ on Expert Advice. https://www.independent.ie/irish-news/irish-water-splashes-5m-on-expert-advice-3 5284262.html

[10] Commission for Regulation of Utilities (CRU) (2019) Irish Water's Household Water Conservation Proposal (Excess Use Charges) CRU Consultation Paper (CRU/19/024). Dublin.

[11] Citizens Information (2016) Household Water Conservation Charge.

http://www.citizensinformation.ie/en/environment/water_services/water_charges.ht $\underline{\mathrm{ml}}$

[12] Finn, C. (2016) Water Meters Are Not the New e-Voting Machines: They Cost a Lot More.

https://www.thejournal.ie/e-voting-machines-water-meters-3114507-Dec2016/

[13] Scottish Water (2019) Unmetered Charges 2018-2019.

https://www.scottishwater.co.uk/you-and-your-home/your-charges/2018-19-charge s/2018-19-umc

[14] Utility Week (2018) Home Truths: Scots Mark Decade of Water Competition. Faversham House Ltd., Wood St, East Grinstead.

[15] Water Industry Commission for Scotland (WICS) (2010) Competition in the Scottish Water Industry. Achieving Best Value for Water and Sewerage Customers. https://www.watercommission.co.uk/UserFiles/Documents/Competition\%20report \%20-\%20final.pdf

[16] RPS \& Veolia Water (2010) The Plan. Water Supply-Project Dublin Region. https://www.dublincity.ie/sites/default/files/content/WaterWasteEnvironment/Wat erSupplyProjectDublinRegion/WaterSupplyProjectDublinRegion/Documents/The\%20Plan.pdf

[17] Blacklocke, S., Bruen, M., Earle, R., Kelly-Quinn, M., O’Neill, E., O’Sullivan, J. and Purcell, P. (2014) Dublin Ireland: A City Addressing Challenging Water Supply, Management, and Government Issues. Ecology and Society, 19, 10. https://doi.org/10.5751/ES-06921-190410

[18] Fitzgerald, J. (2018) Irish Water Split from Ervia Inevitable to Protect Government Accounts.

https://www.irishtimes.com/business/economy/irish-water-split-from-ervia-inevita ble-to-protect-government-accounts-1.3570472

[19] Scottish Water (2017) Annual Report and Accounts 2016/17. Scottish Water, Dunfermline, UK.

[20] Cuthbert J.R. (2018) Inter-Generational Equity and the Strategic Review of Water Charges in Scotland. Fraser of Allander Economic Commentary, 42, 27-35.

[21] Kennelly, J. (2018) Transforming the Water Industry in Ireland: A Local Authority Perspective. Engineers Journal.

http://www.engineersjournal.ie/2018/10/02/transforming-water-industry-ireland-lo cal-authority-perspective/

[22] Irish Water (2013) Irish Water. County Council Service Level Agreement. https://www.housing.gov.ie/sites/default/files/migrated-files/en/Publications/Enviro nment/Water/FileDownLoad\%2C35140\%2Cen.pdf

[23] Brennan, M. (2016) Irish Water Workers Cost Twice as Much as Staff in NI. Sunday 
Business Post.

https://www.businesspost.ie/news/irish-water-workers-cost-twice-as-much-as-staffin-ni-336348

[24] NERA (2016) IW IRC2 (2017-2018) Look forward Submission Assessment. Prepared for the Commission of Energy Regulation (CER).

https://www.cru.ie/wp-content/uploads/2016/07/CER16269-NERA-Review-of-Irish -Water-costs-2017-to-2018.pdf

[25] Finn, C. (2017) Irish Water: We Did Not Waste $€ 70 \mathrm{~m}$ on Consultants. The Journal. https://www.thejournal.ie/irish-water-consultants-3183868-Jan2017/

[26] Duffy, R. (2014) Fianna Fáil Attacks “Gold-Plated Bonus Culture” at Irish Water as Costs Are Revealed. The Journal.

https://www.thejournal.ie/irish-water-uk-comparison-1613268-Aug2014/

[27] Hutcheon, P. (2019) Trio of Scottish Water Executives Take Home $£ 225,000$ in Bonuses. The Herald.

https://www.heraldscotland.com/news/17523139.trio-of-scottish-water-executives-t ake-home-225000-in-bonuses/

[28] Commission for Energy Regulation (CER) (2017) Irish Water's Capital Investment Outputs 2016.

https://www.cru.ie/wp-content/uploads/2017/07/CER17120-Irish-Waters-Capital-I nvestment-Outputs-2016.pdf

[29] Irish Water (2015) Irish Water Business Plan. Transforming Water Services in Ireland to 2021. https://www.water.ie/docs/Irish-Water-Business-Plan.pdf

[30] Scottish Government (2018) Investing in and Paying for Your Water Service from 2021. An Invitation to Provide Your Views.

https://www.gov.scot/publications/investing-paying-water-services-2021/

[31] Dublin City Council (2010) Environmental Report of the Dublin City Development Plan 2011-2017: Strategic Environmental Assessment (SEA). Dublin City Council, Dublin, Ireland.

http://www.dublincity.ie/sites/default/files/content//Planning/DublinCityDevelopm entPlan/Documents/Dev_PlanEnvironmentalReport.pdf

[32] Central Statistics Office (2018) Census 2016 Report: Population Classified by Area. Central Statistics Office, Dublin, Ireland.

https://www.cso.ie/en/csolatestnews/presspages/2017/census2016profile2-populatio ndistributionandmovements/

[33] Audit Scotland (2005) Overview of the Water Industry in Scotland. https://www.audit-scotland.gov.uk/docs/central/2005/nr_051013_water_overview.p df

[34] Commission for Energy Regulation (CER) (2016) Irish Water Second Revenue Control 2017-2018. Consultation Paper.

https://www.cru.ie/wp-content/uploads/2016/07/CER16267-Consultation-on-IrishWater-Revenue-for-2017-to-2018.pdf

[35] Utility Week (2017) Chief Executive's View: Douglas Millican, Scottish Water. Faversham House Ltd., Wood St, East Grinstead.

[36] Water \& Wastewater Treatment (W \& WT) (2019) Transient Detection Helping Scottish Water Prevent Bursts.

https://wwtonline.co.uk/news/transient-detection-helps-scottish-water-predict-burs $\underline{\text { ts }}$

[37] O’Brien, C. (2016) Irish Water to Spend €370m Replacing Lead Pipes in Areas across the Country. The Liberal. 
https://theliberal.ie/irish-water-to-spend-e370m-replacing-lead-pipes-in-areas-acro ss-the-country/

[38] European Commission (EC) (1998) Council Directive 98/83/EC of 3 November 1998 on the Quality of Water Intended for Human Consumption. Official Journal of the European Communities, L330, 32-53.

https://eur-lex.europa.eu/LexUriServ/LexUriServ.do?uri=OJ:L:1998:330:0032:0054: EN:PDF

[39] European Commission (EC) (1991) Council Directive 91/271/EC of 21 May 1991 Concerning Urban Waste Water Treatment. 40-52. https://eur-lex.europa.eu/legal-content/EN/TXT/?uri=celex:31991L0271

[40] EPA (2018) Drinking Water Report for Public Supplies 2017. Environmental Protection Agency, Wexford, Ireland.

[41] EPA (2018) Urban Waste Water Treatment in 2017. Environmental Protection Agency, Wexford, Ireland.

[42] Brady, J. and Gray, N.F. (2017) Reform of the Irish Water Sector: Opportunities and Challenges. Proceedings of the Institution of Civil Engineers-Water Management, 170, 165-174. https://doi.org/10.1680/jwama.15.00106

[43] Dickie, V.A. and Sawkins, J.W. (2001) Affordability of Scottish Water and Sewerage Charges. Quarterly Economic Commentary, 26, 39-47.

[44] Byatt, I. (2012) The Regulation of Water Services in the UK. Utilities Policy, 24, 3-10. https://doi.org/10.1016/j.jup.2012.07.003

[45] Hendry, S. (2016) Scottish Water: A Public-Sector Success Story. Water International, 41, 900-915. https://doi.org/10.1080/02508060.2016.1212961

[46] KPMG (2018) Annual Audit Report to the Members of Scottish Water and the Auditor General for Scotland.

https://www.audit-scotland.gov.uk/uploads/docs/report/2018/aar_1718_scottish_wa ter.pdf

[47] OFX (2019) Yearly Average Rates. https://www.ofx.com/en-gb/forex-news/historical-exchange-rates/yearly-average-ra tes/

[48] Irish Water (2017) Irish Water Financial Statements as at 31 December 2016. http://www.ervia.ie/site-files/docs/who-we-are/iw_financial_statements_2016.pdf

[49] Scottish Water (2018) Annual Report and Accounts 2017/18. https://docs.google.com/viewerng/viewer?url=www.scottishwater.co.uk/-/media/Sc ottishWa-

ter/Document-Hub/Key-Publications/Annual-Reports/230718ScottishWaterAnnual Report1718.pdf

[50] IFRS Foundation (2017) Who Uses IFRS Standards? https://www.ifrs.org/use-around-the-world/use-of-ifrs-standards-by-jurisdiction/\#p $\underline{\text { rofiles }}$

[51] National Records of Scotland (NRS) (2019) Population of Scotland. https://www.nrscotland.gov.uk/statistics-and-data/statistics/scotlands-facts/populati on-of-scotland

[52] Worldometers (2019) Ireland Population Live http://www.worldometers.info/world-population/ireland-population/

[53] Statista (2017) Ireland: Urbanisation from 2017 to 2017. https://www.statista.com/statistics/455844/urbanization-in-ireland/

[54] National Statistics (2011) Rural Scotland Key Facts 2011. People and Communities, 
Services and Lifestyle, Economy and Enterprise.

https://www.webarchive.org.uk/wayback/archive/20170105172301/http://www.gov. scot/Publications/2011/09/29133747/7

[55] Scottish Water (2018) Delivery Plan 2015-2021.

https://www.scottishwater.co.uk/en/Help-and-Resources/Document-Hub/Key-Publ ica-

tions/www.scottishwater.co.uk/-/media/ScottishWater/Document-Hub/Key-Public ations/Delivery-and-Business-Plans/1604192019DeliveryPlanUpdateVersionForPub lication.pdf

[56] MarketLine (2018) Company Profile: Scottish Water. https://www.researchpool.com/provider/marketline/scottish-water-strategy-swot-a nd-corporate-finance-report/

[57] Irish Water (2016) Interim Revenue Control 2017-2018. Investment Plan 2017-2021. https://www.cru.ie/wp-content/uploads/2016/07/CER16274-Irish-Water-IRC2-Sub mission-Executive-Summary-2017-to-2018.pdf

[58] Irish Water (2018) Irish Water Annual Report and Financial Statements 2017. http://www.ervia.ie/ervia-annual-report/19843_Irish_Water_AR_2017_Full_V16.pd f

[59] European Commission (EC) (2000) Council Directive 2000/60/EC of 23 October 2000 Establishing a Framework for Community Action in the Field of Water Policy. L327, 1-73.

https://eur-lex.europa.eu/legal-content/EN/TXT/?uri=CELEX\%3A32000L0060

[60] EPA (2019) EPA Drinking Water Remedial Action List Q4 of 2018. http://epa.ie/pubs/reports/water/drinking/drinkingwaterralq42018.html

[61] Irish Water (2018) Leakage Reduction Programme. First Fix Leak Repair Scheme for Domestic Water Customers. Quarterly Report. Q4 2017. https://www.water.ie/for-home/first-fix/Quarter-4-report-2017.pdf

[62] Water Industry Commission for Scotland (WICS) (2013) Scottish Water's Performance 2012-13.

https://www.watercommission.co.uk/UserFiles/Documents/WICS\%20Performance \%202012-13.pdf

[63] Water Industry Commission for Scotland (WICS) (2014) Scottish Water's Performance 2013-14.

https://www.watercommission.co.uk/UserFiles/Documents/Performance\%20Report \%202013-14\%20(final\%20web\%20version).pdf

[64] Water Industry Commission for Scotland (WICS) (2015) Scottish Water's Performance 2014-15.

https://www.watercommission.co.uk/UserFiles/Documents/Performance\%20Report \%202014-15.pdf

[65] Water Industry Commission for Scotland (WICS) (2016) Scottish Water's Performance 2015-16.

https://www.watercommission.co.uk/UserFiles/Documents/2015-16\%20Performan ce\%20Report\%20FINAL\%20PDF.pdf

[66] Water Industry Commission for Scotland (WICS) (2017) Our Initial Expectations: Note 7 for the Customer Forum. Financial Tramlines.

https://www.watercommission.co.uk/UserFiles/Documents/CustomerForumNote7. pdf

[67] Water Industry Commission for Scotland (WICS) (2018) Scottish Water's Performance 2017-18. 
https://www.watercommission.co.uk/UserFiles/Documents/2017-18_Performance\% 20Report.pdf

[68] Scottish Water (2019) Delivery Plan 2015-2021. Delivery Plan Update 2019. March 2019.

https://docs.google.com/viewerng/viewer?url=www.scottishwater.co.uk/-/media/Sc ottishWa-

ter/Document-Hub/Key-Publications/Delivery-and-Business-Plans/1604192019Deli veryPlanUpdateVersionForPublication.pdf

[69] Irish Water (2016) Irish Water Financial Statements as at 31 December 2015. http://35.189.110.21/site-files/docs/who-we-are/Financial\%20Statements\%20for\%20 Ervia\%20Group\%20Companies/2015/Irish-Water-Financial-Statements-2015.pdf

[70] Irish Water (2018) Strategic Funding Plan 2019-2024. https://www.housing.gov.ie/sites/default/files/publications/files/irish_water_strategi c_funding_plan.pdf

[71] Scottish Water (2016) Annual Report and Accounts 2015/16. https://www.scottishwater.co.uk/en/Help-and-Resources/Document-Hub/Key-Publ ications/www.scottishwater.co.uk/-/media/ScottishWater/Document-Hub/Key-Public ations/Delivery-and-Business-Plans/1604192019DeliveryPlanUpdateVersionForPub lication.pdf

[72] Office of the Comptroller and Auditor General (2017) Report on the Accounts of the Public Services 2016. Chapter 1 Exchequer Financial Outturn for 2016.

https://www.audit.gov.ie/en/Find-Report/Publications/2017/Chapter1-Exchequer-F inancial-Outturn-for-2016.pdf

[73] Office of the Comptroller and Auditor General (2018) Report on the Accounts of the Public Services 2017. Chapter 1 Exchequer Financial Outturn for 2017.

https://www.audit.gov.ie/en/Find-Report/Publications/Report\%20on\%20the\%20Ac counts\%20of $\% 20$ the $\% 20$ Public\%20Services/Report-on-the-Accounts-of-the-PublicServices-2017.pdf

[74] Scottish Water (2014) Business Plan 2015-2021.

https://docs.google.com/viewerng/viewer?url=www.scottishwater.co.uk/-/media/Sc ottishWater/Document-Hub/Key-Publications/Delivery-and-Business-Plans/040419SWBusi nessPlan2015to21.pdf

[75] Rodriguez-Sanchez, C., Schuitema, G., Claudy, M. and Sancho-Esper, F. (2018) How Trust and Emotions Influence Policy Acceptance: The Case of the Irish Water Charges. British Journal of Social Psychology, 57, 610-629.

https://doi.org/10.1111/bjso.12242

[76] Water Industry Commission for Scotland (WICS) (2013) Note 18 for the Customer Forum. Scottish Water's Draft Business Plan: Base Expenditure.

https://www.watercommission.co.uk/UserFiles/Documents/CustomerForumNote18 (B).pdf

[77] Water Industry Commission for Scotland (WICS) (2017) Scottish Water's Performance 2016-17.

https://www.watercommission.co.uk/UserFiles/Documents/WICS_PerformanceRep ort2016-17_12.10.pdf

[78] CH2M Hill (2014) IW Interim Review 2014-2016 Assessment of Capital Expenditure. Final Report. Prepared for NERA.

https://www.cru.ie/wp-content/uploads/2014/07/CER14371-C3-Halcrow-Report-on -Irish-Water-Interim-Review-2014-2016-Assesment-of-Capital-Expenditure.pdf 
[79] Commission for Regulation of Utilities (CRU) (2018) Irish Water Revenue Control 2019 Revenue Control 2 (2017/2018) One-Year Extension (CRU/18/211). https://www.cru.ie/wp-content/uploads/2018/10/CRU18225-Update-to-Irish-Water -Revenue-Sources-in-CRU-Decision-CRU-18-211.pdf

[80] Irish Water (2016) Interim Revenue Control 2017-2018. Investment Plan 2017-2021. Irish Water, Dublin.

[81] Scottish Water (2014) Always Serving Scotland. Business Plan 2015 to 2021. Appendices.

https://docs.google.com/viewerng/viewer?url=www.scottishwater.co.uk/-/media/Sc ottishWa-

ter/Document-Hub/Key-Publications/Delivery-and-Business-Plans/040419SWBusi nessPlan2015to21Appendices.pdf

[82] Population Pyramid (2019) Population of Ireland 1950 to 2050.

https://www.populationpyramid.net/ireland/2050/

[83] Tretsiakova-McNally, S., Solan, B., Currie, R., Akinsanmi, O., Arnscheidt, J., McDermott, R. and Heather, C. (2019) A Ligno-Cellulosic Bio-Adsorbent Derived from Sawdust Waste for the Removal of Meropenem Antibiotic Dissolved in Water. Proceedings of the European Waste Water Management Conference, Birmingham, 15-17 July 2019.

[84] McDermott, R., Strong, A. and Griffiths, P. (2019) Solid Transfer in Low Flow Sewers, the Distance Travelled So Far Is Not Enough. Journal of Environmental Protection, 10, 164-207. https://doi.org/10.4236/jep.2019.102011

[85] Kelly, F. (2018) Cabinet Set to Approve Water Supply Referendum Outline. The Irish Times.

https://www.irishtimes.com/news/politics/cabinet-set-to-approve-water-supply-refe rendum-outline-1.3703483

[86] Irish Water (2019) Safe Guarding Our Water for Our Future. Advertisement of Sky One Television.

[87] Brennan, M. (2019) Bloated Irish Water Ordered to Cut Costs by $€ 100$ Million. The Business Post.

https://www.businesspost.ie/news/bloated-irish-water-ordered-cut-costs-e100-milli on-449944 